\title{
CONFLICT IN THE CHURCH: THE UNCOMFORTABLE REALITY
}

\author{
John Paul Lathrop ${ }^{1)^{*}}$ \\ 1) Alumnus Gordon-Conwell Theological Seminary in Urban Ministry \\ *) Authors Correspondence: john.p.lathrop@gmail.com
}

\begin{abstract}
The apostle Paul, writing to Timothy, said "If anyone sets his heart on being an overseer, he desires a noble task" (1 Tim. 3:1, NIV). The work is definitely noble but the task is not always easy. Timothy knew that because he was in the troubled church of Ephesus at the time when Paul wrote to him. Paul also knew that the ministry is difficult. Conflict is all too often a part of Christian ministry. In this brief article, we explore three kinds of conflict that a minister may encounter in the church. Paul was experienced in all of them and so I will focus our attention on his experience.
\end{abstract}

Keywords: conflict, church, Christian, Timothy, Paul, ministry

Rasul Paulus menuliskan kepada Timotius, katanya "Orang yang menghendaki jabatan penilik jemaat menginginkan pekerjaan yang indah" (1 Tim. 3:1, ITB). Pekerjaan ini memang sangat mulia namun tugas ini tidak selalu mudah. Timotius mengetahui hal itu karena ia berada dalam gereja yang bermasalah di Efesus pada saat itu Paulus menuliskan surat ini kepadanya. Paulus juga tahu bahwa pelayanan ini tidaklah mudah. Konflik yang terjadi merupakan bagian dari pelayanan orang Kristen. Dalam artikel ini, kita menyelidiki tiga jenis konflik yang mungkin akan dihadapi seorang pelayan di gereja. Saat itu Paulus mengalami semua konflik tersebut dan penulis akan fokus memberikan perhatian pada pengalaman pelayanannya.

Kata-kata kunci: konflik, gereja, Kristen, Tomotius, Paulus, pelayanan

\section{Introduction}

Conflict. It seems to be found in almost every area of life in our world; it is even found in the church. The presence of conflict among the people of God is confirmed by both Scripture and experience. A simple reading of the New Testament will show that the early church experienced conflicts of different kinds among its own members. In addition, if you have been a Christian for any length of time, and especially if you have been involved in Christian leadership in any capacity, then you know that conflict is still very much with us today. In his book Body Life pastor Ray Stedman includes a humorous little rhyme that is descriptive of this challenging aspect of church life. 
To dwell above with saints we love,

Oh that will be glory.

But to live below, with saints we know;

Well, that's a different story!

In my book, Answer the Prayer of Jesus: A Call for Biblical Unity, I say that this rhyme "may be closer to home than we would like to admit." 2

Conflict in the church is almost inevitable and it exists for a variety of reasons. In many cases it can be counterproductive and very painful; it saps our strength, troubles our emotions, and strains our relationships. At other times conflict, though painful, may be necessary for the health and wellbeing of the church. In this brief article we will survey texts that set forth three different types of conflict that the early church experienced. All of the examples that I will cite involve the apostle Paul. That being said, one need not be an apostle to encounter conflict in the church. Pastors, teachers, evangelists, deacons and others can also experience it. In fact, anyone serving in Christian ministry can find themselves involved in conflict. All of the texts that we will look at concern disputes between believers. I will not address the believer's conflict with evil spirits (Eph. 6:10-12) or with unbelievers (Mark 13:13; John 17:14). The three areas of conflict I will focus on are: those between spiritual leaders, between church members, and between a spiritual leader and a congregation. The purpose of this brief study is to acquaint the reader with the types of conflict that one can encounter in the church, help him or her identify the issues involved, and help prepare them to handle these conflicts when they arise.

\section{Conflict Between Spiritual Leaders}

The first type of conflict that we will consider is probably the most disturbing and perhaps also the most disappointing. I am referring to conflict between church leaders. Spiritual leaders are typically people of mature Christian experience, who are knowledgeable of the Scriptures and, according to the New Testament pattern, are to be filled with the Holy Spirit. Stated differently, they are people of high spiritual standards. Since this is so, we expect good things from them, and conflict is not one of them. In view of the fact that they are using the same Bible and are partakers of the same Holy Spirit it seems logical to think that they would always agree, right? Unfortunately, this is not

\footnotetext{
${ }^{1}$ Ray C. Stedman, Body Life (Ventura, CA: Regal, 1972), 24-25.

${ }^{2}$ John P. Lathrop, Answer the Prayer of Jesus: A Call for Biblical Unity (Eugene, OR: Wipf \& Stock, 2011), 32.
} 
always the case. The text we will use for our discussion of this type of conflict is Acts 15:36-41.

In this passage we read about a conflict between Paul and Barnabas. This turn of events is a bit of a surprise in view of the two people involved and their history together. They came from different places, Paul came from Tarsus in Cilicia (Acts 22:3) and Barnabas came from the Island of Cyprus (Acts 4:36) but they had a lot of things in common: both were men, both were Jewish (Phil. 3:5; Acts 4:26), both were Christians, both were apostles (Acts 14:14), and both were filled with the Holy Spirit (Acts 9:17; 11:24). These men had similar Christian experiences and ministries. In addition, Paul and Barnabas had a significant history of working together. As co-workers they taught the church in Antioch for a year (Acts 11:25-26), they went on a missionary journey together (Acts 13-14), and they traveled together to the Council in Jerusalem and spoke there (Acts 15:2, 12). Paul was in some sense in Barnabas's debt in that Barnabas helped the new believer Paul gain acceptance in the church in Jerusalem (Acts 9:26-28). Barnabas was also the person who enlisted Paul to teach in the church in Antioch (Acts 11:25-26). Paul's acceptance by the church and participation in ministry were in some measure due to Barnabas' influence. It is clear from other texts in the New Testament that Barnabas was respected in the early church. For example, he was the one sent from the Jerusalem church to see what God was doing in Antioch (Acts 11:22). There is no question that Paul was also well regarded in the church (Acts 15:25; Gal. 2:9). So how is it that such quality people had a falling out? Acts 15:39 says, "They had such a sharp disagreement that they parted company" (NIV). What precipitated this severe conflict that caused these friends and coworkers to part company? Let us turn to the text to answer this question.

Acts 15:37-38 tells us that they were divided about a man named John Mark. This man had been with Paul and Barnabas on their first missionary journey but had left them (Acts 13:13). The reason for his departure is not specified. John Stott says concerning this text, "Luke announces the fact in a matter-of-fact manner and appears to apportion no blame." ${ }^{3}$ However, Stott goes on to point out that in Acts 15:38 John Mark's departure is not seen in a favorable light in that the text says that he "deserted" Paul and Barnabas. ${ }^{4}$ We cannot say with certainty why he left because the Bible does not tell us. What we do know is that this issue had a family dynamic to it; John Mark was a cousin to Barnabas (Col. 4:10).

\footnotetext{
${ }^{3}$ John Stott, The Spirit, the Church and the World: The Message of Acts (Downers Grove, IL: InterVarsity, 1990), 221.

${ }^{4}$ Ibid., 221.
} 
All Christians are part of the "family of believers" (Gal. 6:10, NIV); through the blood of Jesus we have all become brothers and sisters in the Lord. But some members of the family of believers are actually blood relatives. Never minimize the significance of this, for whether intentionally or not, this dynamic can exert great influence on decisions in the context of the church. I have seen it happen more than once.

I am not suggesting that either Paul or Barnabas had ill motives in this disagreement in Acts 15, not at all. I think that both genuinely wanted to honor and serve the Lord, but they had different ideas about what would be the most productive way to achieve these ends. Paul was a man of high standards. He had them for himself, and I am sure he had them for others as well. This being the case, John Mark did not rank very high on Paul's list at the time because of his previous desertion of the missionary team. This does not mean that John Mark was a bad person; he just did not measure up to Paul's standards or expectations. Barnabas, on the other hand, was an encourager. He encouraged Paul shortly after he had become a follower of Jesus and he encouraged the new believers in the church at Antioch (Acts 11:22-23). This was his lifestyle. He was one who was willing to give another the benefit of the doubt. He was probably even more willing to give someone the benefit of the doubt if the person was a relative, such as his cousin, John Mark.

As Christians we know that our character is to be like the Lord's and one of His character traits is being impartial (James 2:1). However, being impartial is often more difficult than we think. There are things that impact our decision-making processes and thus, our choices, things like who we are and who the other people involved are. In reality, few, if any of us, are totally unbiased. We need to recognize this both in ourselves and also in others. These are the realities of life, even in the church.

So who was wrong in this case Paul or Barnabas? I used to think that Paul was in error here. However, this is not an easy question to answer, for two reasons. First, the issue is not a moral issue. That is, there is no direct commandment in Scripture that has been violated here. Second, the Bible does not give us a definitive answer. Regarding this parting of the ways in Acts 15, New Testament scholar, Craig Keener, has written "Luke surely intends us to see the Lord's blessing on the new Paul-Silas team (Acts 15:40; 16:37) but this does not signal his approval of the dispute between Paul and Barnabas, handled so unlike the council in 15:22." Both Barnabas and Paul experienced the same desertion by John Mark but they had differing opinions about how to go on from there. It

${ }^{5}$ Craig S. Keener, The IVP Bible Background Commentary: New Testament (Downers Grove, IL: InterVarsity, 1994), 366. 
seems that Paul later made peace with John Mark. Walter L. Liefeld points out in his comments on 2 Timothy 4:11 that there must have been a change in Paul, Mark, or both of them so that Paul once again trusted him as an associate in the apostle's ministry. ${ }^{6}$

When leaders have a disagreement with each other the best biblical course of action to pursue is reconciliation. However, as Acts 15 makes clear this does not always take place immediately (in some cases it never takes place). There are a variety of reasons for this. One of the main reasons is pride; both parties in the disagreement think that they are right. One of the unhappy realities of ministry is that we cannot fix everything in an instant; in fact, in some cases there are things that we can never fix. I believe that the Lord's highest idea for his people is unity. This is what Jesus prayed for in John 17. It is also one of the major themes in Paul's writings (and he was one of the parties involved in the conflict in Acts 15). However, when reconciliation does not take place it is better, as in this case, for the leaders to go their separate ways rather than to stay together and disagree. Parting ends the stalemate and the work of God can go on. Both Paul and Barnabas went on in ministry (Acts 15:3941). Be prepared for conflicts with fellow ministers, as they will come, but do all that you can to diffuse them without compromising biblical principles.

\section{Conflict Between Church Members}

The apostle Paul had a lot of experience in dealing with disputes between church members. I believe that this type of conflict is more prevalent than the conflict between Christian leaders. This is at least in part, due to the fact that there are more people who can potentially be involved. There are more people in a church than there are leaders in the church. Support for the assertion that conflicts between church members are more prevalent than conflicts between leaders can be found in Paul's letters. Read through his letters and you will find multiple texts where he is dealing with discord between believers. Some of his letters that deal with conflict between members of the congregation include: Romans, l Corinthians, Ephesians, and Philippians. It was a common problem and was widespread: and it still is! After 2,000 years of church history we still have the problem today. As the book of Ecclesiastes says, "there is nothing new under the sun" (Eccles.l:9b, NIV). If you desire to pastor a large church or contemplate a large ministry consider this: more people means more problems.

${ }^{6}$ Walter L. Liefeld, The NIV Application Commentary: 1 \& 2 Timothy, Titus (Grand Rapids, MI: Zondervan, 1999), 297. 
The New Testament affords us a wealth of material related to this kind of conflict but I would like us to focus our attention on the church in Corinth. I half jokingly say that this church is every pastor's dream. If it is a dream church, then the dream is in some measure a nightmare! They were blessed in many ways: they were Christians and recipients of God's grace (1 Cor. 1:4), they had been enriched in their speaking and knowledge (1 Cor. 1:5), and they had received spiritual gifts (1 Cor. 1:7). But they were fraught with division. Let us now consider some of the conflicts in this church.

The apostle Paul founded the church in Corinth during one of his missionary journeys (Acts 18). He was thus very acquainted with the church there. When he wrote the book that we know as 1 Corinthians he was not present with them. He wrote to them due to reports that he had heard about them (1 Cor. 1:11; 5:1; 11:18) and to answer questions they had sent to Paul in a letter. ${ }^{7}$ Let us now focus on the issue of their conflicts, which were multi-faceted.

Evidence of discord, indeed conflict, can be found especially in 1 Corinthians 1, 6, 11, and 12-14. In chapter one, we see that they are divided in their preference or commitment to different ministers: "I follow Paul"; another "I follow Apollos"; another, "I follow Cephas"; still another, "I follow Christ" (1 Cor. 1:12, NIV). In chapter six, we find that there were lawsuits between some members of the church (1 Cor. 6:1-8). In chapter eleven, they were not treating one another rightly at the communion service (1 Cor. 11:17-22; 33-34). Dr. Gordon Fee believes that the Corinthians were abusing the poor at the communion service by not leaving them anything to eat. ${ }^{8}$ In chapters twelve through fourteen, we see that there is disorder and dissention regarding spiritual gifts ( 1 Cor. 14:40; 14:12). In each of these scenarios, their behavior was not what it should have been because of an improper or deficient understanding of who they were as the church, the people of God. The Corinthian believers did not seem to realize that they were members of one body, members of one another. As a result of their lack of theological understanding of what it means to be the body of Christ their behavior suffered. They were not living as God intended them to because they did not understand who God made them to be. Paul sought to correct these situations through his instruction.

Paul did not shrink back or waver in dealing with this fractured and fragmented church. He brought truth to bear on the specifics of their corporate life. The believers in Corinth needed to have their minds renewed in order to "fix" their corporate experience. Paul gave the

${ }^{7}$ Gordon D. Fee, The First Epistle to the Corinthians. The New International Commentary on the New Testament (Grand Rapids, MI: Wm B. Eerdmans, 1987), 5.

${ }^{8}$ Ibid., 534-536. 
church the proper perspective about their leaders; he told them that the leaders were servants who were doing the work that the Lord gave each of them to do (1 Cor. 3:5). Concerning their law cases with one another he told them that cheating their brothers and sisters in the Lord was not only wrong (1 Cor. 6:8) but that it was a poor testimony to bring their grievances with one another to court before non-believers (1 Cor. 6:6). Concerning spiritual gifts, Paul told the church that though there is variety in the gifts, they all come from the same God, and they are given for the benefit of the church as a whole (1 Cor. 12:1-11). There is a correlation between belief and behavior: beliefs impact behavior. When it comes to fixing problems and bringing a church together it takes more than people skills, as valuable as they are, it takes truth, truth that is thoroughly explained! Paul took time to address each of these situations in some detail.

We live in a day, at least in the West, when people are not especially fond of doctrinal instruction or systematic theology. Many churches no longer offer Sunday school classes and from what I have seen a good portion of the preaching on Sunday morning is not expositional. I think that these are unfortunate turns of events. Many of the problems in our churches today could be averted, or remedied, if people knew their Bibles well. We need leaders who will follow Paul's example and give their churches clear and well-reasoned presentation of truth. I realize that in some parts of the world Christians do not have Bibles or have limited access to them. This also holds true of good study materials. But where these resources are available they need to be used. This being said, I know that this course of action in and of itself will not fix everything, because people have free will and they can choose to obey or disobey the clear teachings of Scripture. Paul loved the people in the Corinthian church enough to confront the errors in their congregation. The spiritual health and growth of the church depended on it.

In the ministry there will frequently be people in conflict with each other. Even if you are not directly involved in it as a leader, you have a responsibility to attempt to bring things back into biblical order. This is part of the job description for apostles, prophets, evangelists, pastors, and teachers (Eph. 4:11-13). It is best not to let unbiblical beliefs and practices continue, they only tend to get worse. It is better to deal with the issues when they are small; deal with them directly and decisively. This is Paul's model. It may not always be easy, but it is part of the calling of a Christian leader. 


\section{Conflict Between a Church Leader and a Congregation}

As we finish up our brief survey of the various kinds of conflict that one may encounter in ministry, we will once again look at the experience of the apostle Paul. And here too we will focus on his experience with the church at Corinth; although this time we will look at the book of 2 Corinthians. The type of conflict that we will look at in this section is the conflict between a spiritual leader and a congregation. This type of conflict is quite common in ministry. This too can happen for various reasons; sometimes it is due to the sins or errors of the minister, at other times it is due to the sins or errors of the congregation. Sometimes it is due to misunderstandings of either or both parties. However, the case that we will be looking at is one in which the minister is not at fault.

As was stated earlier the apostle Paul founded the church at Corinth (Acts 18); he was its spiritual father (1 Cor. 4:15). He spent a significant amount of time in the city and invested himself in the lives of the people by teaching them (Acts 18:11). However, his spiritual children did not always give him the respect that he deserved. On the contrary, there were times when they were quite contemptuous toward him. More specifically, they did not respect his authority and even resorted to maligning his public speaking (2 Cor. 11:5; 10:10). As we read the book of 2 Corinthians we can see that the attacks against Paul were very personal in nature. This teaches us a very sobering truth: proper respect is not always given to the person who is called, anointed, and given authority by God. This is perhaps especially true if the leader has offered correction to the church, as Paul had done in his earlier letter, the one that we know as 1 Corinthians. It is part of our sinful human nature to resist or resent teaching that tells us that we must change.

Now, Paul had earlier written to the Corinthian church and admitted to them that his preaching was not very impressive by human standards. Later they took issue with him over his public speaking, they said that his letters were forceful but that his personal presentations were not (2 Cor. 10:10). However, they were forgetting something. It is true that Paul's message was very simple and direct; it focused on Jesus Christ (1 Cor. 2:2), but he had the power of God attending it (1 Cor. 2:4). Paul had the power of God, the blessing of God upon his public speaking; the existence of the Corinthian church was proof of that! He was blessed in this way because he was declaring the truth. Content is the most important thing in preaching. People often attack the minister's preaching and teaching (because it is done in public). Some are also known to be very taken by a charismatic speaker, one who can move a crowd by their delivery or emotion. This is the wrong measuring stick to use on Christian preaching and teaching. 
The Corinthians also took issue with Paul's authority. That may have threatened another minister but Paul never budges on this issue. He is unwavering in saying that he has authority (2 Cor.10:8; 13:10) and he states plainly that it has been given to him for a redemptive purpose, to build them up, not to tear them down. He is very secure in his authority because it is linked to his apostleship, which he is quite confident of (1 Cor. 1:1; 2 Cor. 1:1; Gal. 1:1). This probably explains how he could stand strong in the face of the opposition that he encountered from the Corinthian church. Not many of us have experienced as powerful a call to ministry as Paul did (Acts 9; 22; 26), but that does not mean that it is any less divine. God is the one who calls apostles, prophets, evangelists, pastors, and teachers (Eph. 4:11) and we need to take confidence in that truth, especially when we encounter conflict in our ministry.

Attacks on a minister's preaching and authority can be painful. The leader is outnumbered and may in many cases stand alone. This is not a comfortable place to be; even if you are physically distant from the situation, as Paul was in this case. A leader can feel deeply wounded if he or she is disrespected by people who ought to be giving them respect. Paul should have been respected because he was the spiritual father of the church and had invested much into the lives of the people. He sought to love them more, but they appeared to love him less (2 Cor. 12:15). When you are helping people you can get hurt in the process.

We do not know all that Paul felt, but no doubt there was some frustration on his part. He does not allow the disrespect leveled at him to shake his confidence in the fact that he has authority in the Lord (2 Cor. 10:8; 13:10). As David was able to find strength in God (1 Sam. 30:6), church leaders need to do the same and be prepared for such conflicts in the church. They do come and they are not a one time event.

\section{Conclusion}

In this brief article we have looked at three types of conflict that existed between believers in the New Testament church: leaders having a conflict with each other, people in a congregation at odds with one another, and a leader having a conflict with those that he has authority over. These same conflicts exist in today's church. When they occur they must be dealt with in a positive and redemptive way. This is not always easy to do. The conflict should not be a battle of wits or wills. Rather, those involved should be trying to find the will of the Lord in the matter.

When you face conflict in the ministry seek the Lord and realize that you are not alone, you are also not the only one who has had to deal with it. You might also do well to do a more detailed study of how Paul responded in situations of conflict (as he had a lot of experience with it). 
God's work must go on. The ministry is a glorious calling; hold your course when the storms come. Remember your call is "to prepare God's people for works of service, so that the body of Christ may be built up until we all reach unity in the faith and in the knowledge of the Son of God and become mature, attaining to the whole measure of the fullness of Christ" (Eph. 4:12-13, NIV).

\section{Bibliography}

Fee, Gordon D. The First Epistle to the Corinthians. The New International Commentary On the New Testament. Grand Rapids, MI: Wm B. Eerdmans, 1987.

Keener, Craig S. The IVP Bible Background Commentary: New Testament. Downers Grove, IL: InterVarsity, 1994.

Lathrop, John P. Answer the Prayer of Jesus: A Call for Biblical Unity. Eugene, OR: Wipf \& Stock, 2011.

Liefeld, Walter L. The NIV Application Commentary: 1 \& 2 Timothy, Titus. Grand Rapids, MI: Zondervan, 1999.

Stedman, Ray C. Body Life. Ventura, CA: Regal, 1972.

Stott, John. The Spirit, the Church and the World. Downers Grove, IL: InterVarsity, 1990. 